\title{
DINAMIKA PARAMETER OSEANOGRAFI TERHADAP HASIL TANGKAPAN IKAN TERI (Stolephorus Spp) PADA BAGAN PERAHU DI TELUK DODINGA, KABUPATEN HALMAHERA BARAT
}

\author{
The Dinamic of Oceanographic parametres to Anchovies catched at \\ Boat Lived Nets in Dodinga Bay,West Halmahera Districs
}

\author{
John Karuwal* \\ Jurusan Manajemen Sumerdaya Perairan, UNIDAR, Ambon, 97128, Indonesia \\ *Korespondensi: j_karuwal@yahoo.com
}

\begin{abstract}
ABSTRAK
Ikan teri (Stolephorus spp) merupakan hasil tangkapan utama perikanan bagan perahu di Teluk Dodinga. Kehidupan ikan teri seperti ikan pelagis kecil lainnya juga membutuhkan parameter kondisi lingkungan perairan yang sesuai. Penelitian ini bertujuan mengetahui dinamika parameter oseanografi terhadap hasil tangkapan Bagan Perahu di Teluk Dodingga Kabupaten Halmahera Barat. Data parameter oseanografi perairan berupa suhu permukaan laut, salinitas, kecerahan, kecepatan arus, kecepatan angin dan hasil tangkapan ikan teri dikumpulkan secara in situ. Analisis data dilakukan secara deskriptif dan statistik untuk menerangkan hubungan antar faktor menggunakan regresi linear berganda. Hasil uji $\mathrm{F}$ menunjukan bahwa secara bersama-sama semua faktor oseanografi berpengaruh nyata terhadap hasil tangkapan ikan teri dengan nilai $\mathrm{F}_{\text {hitung }}$ sebesar 9.058 dan nilai signifikansi kurang dari 0.004 sedangkan hasil uji $t$ menunjukan bahwa secara individu hanya kecepatan angin yang berpengaruh nyata terhadap hasil tangkapan ikan teri dengan nilai signifikasi sebesar -3.010 dengan nilai signifikansi $0.004(\alpha=(0.05)$. Model persamaan regresi untuk menjelaskan hubungan kecepatan angin dan hasil tangkapan teri adalah $\widehat{y}=26.666-72.513 X_{I}+\boldsymbol{e}$. Selanjutnya didapat pula bahwa hasil tangkapan ikan teri (Stolephorus spp) yang optimal pada teluk Dodinga pada rentang suhu permukaan laut $24-28{ }^{\circ} \mathrm{C}$, Salinitas sebesar $25-30 \mathrm{ppt}$, kecepatan angin sebesar $0-2,5$ meter/detik, kecepatan arus sebesar 0,1-0,7 meter/detik dan kecerahan perairan sebesar 8-11 meter.
\end{abstract}

Kata kunci: parameter oseanografi; ikan teri (Stolephorus spp); bagan perahu

\begin{abstract}
Teri (Stolephorus spp) is the mainly catched of boat life nets in Bodinga Bay, West Halmahera district. The life of teri like other small pelagic fish was needed seas parameter as well as Its live needed. The aims of this study are to know the dynamic of sea's parameter affected to boat liftnets catched in Dodinga Bay. The data of water's parameters like sea surface temperature, salinity, water brightness, current velocity, wind speed and teri's catches are collected by in situ way. Data analysis by using descriptic and statistic method to explain the connection between the factors with multiple linear regression method. The result of $\mathrm{f}$ test showing that all water's parameters is together had have real impact on fish catches with $\mathrm{f}_{\text {count }}$ is 9.058 and significant values is less than 0.004 while the $t$ test show that in individual parameter only wind speeds are had have real impact on teri catches with t test value is-3.010 at significant value is $0.005(\alpha=($ 0.05 ). The regression equation formed to explain the wind speed and anchovies catch him are $\widehat{y}=526.666-72.513 X_{I}+\boldsymbol{e}$. Furthermore get also that the optimal of teri
\end{abstract}


(Stolephorus spp) catches at Dodinga Bay was occurs on range of sea surface temperature are $24-28^{\circ} \mathrm{C}$, salinitas of $25-30 \mathrm{ppt}$, wind speed of $0-2,5 \mathrm{~m} / \mathrm{s}$, current velocity are $0,1-$ $0,7 \mathrm{~m} / \mathrm{s}$ and the brightness of waters are $8-11$ meters.

Key word: oceanography parameters; teri (Stolephorus spp); boat lifetnet

\section{PENDAHULUAN}

Perairan Teluk Dodinga di Kabupaten Halmahera Barat telah lama menjadi daerah operasi penangkapan bagi bagan perahu di propinsi Maluku Utara. Parameter oseanografi yang berkaitan erat dengan distribusi ikan antara lain kelimpahan plankton, suhu, kecepatan arus, salinitas dan lainnya.

Faktor ini sangat bermanfaat untuk pemanfaatan dan pengelolaan sumberdaya ikan, terutama dalam usaha penangkapan. Dinamika faktor oseanografi yang cenderung berubah mengikuti ruang dan waktu dapat menyebabkan perubahan adaptasi dan tingkah laku ikan target, dimana setiap jenis ikan memiliki kemampuan adaptasi yang berbeda terhadap kondisi oseanografi untuk kelangsungan hidupnya. Oleh sebab itu maka adanya sebaran klorofila, suhu dan perubahannya serta pola arus yang terjadi akan mempengaruhi ikan dalam beraktivitas terutama dalam mencari makan, bertelur, melakukan ruaya dan migrasi.

Daerah penangkapan ikan teri (stolephorus spp), di perairan Teluk Dodinga dapat diketahui dengan memperhatikan parameter oseanografi, seperti suhu,kecepatan arus, dan salinitas. Hal ini disebabkan karena setiap spesies ikan memiliki kisaran suhu tertentu yang sesuai dengan kebiasaan hidupnya yang dapat ditoleransi oleh tubuhnya sehingga dapat mempengaruhi penyebaran ikan di suatu perairan. Dengan cara membandingkan keberadaan ikan yang tertangkap dengan suhu permukaan laut yang disukainya, keberadaan ikan teri dan jenis ikan lain dapat diketahui.

Bagan perahu (boat lift net) adalah jenis kapal yang beroperasi dengan menggunakan alat tangkap jaring dengan tujuan penangkapan adalah jenis ikan pelagis kecil yang dapat berpindah dari satu daerah penangkapan ke daerah penangkapan lainnya (Baskoro, 1999). Ikan yang menjadi target penangkapan bagan perahu adalah ikan pelagis kecil yang memiliki sifat fototaksis positif (tertarik pada cahaya) seperti teri (stolephorus spp), tembang (sardinella fimbiata), kembung (Rastrelliger spp), selar (Selaroides $s p), \quad$ layang (Decapterus spp), peperek (Leiognathus $s p$ ), layur (Trichiurus savala) dan cumicumi (Loligo $s p$ ). Ikan teri merupakan target utama dalam pengoperasian alat tangkap bagan perahu yang beroperasi di perairan teluk Dodinga Kabupaten Halmahera Barat. Luasunaung, 2011 menyatakan bahwa kurun waktu 20052009, teluk Dodinga telah memberikan kontribusi ikan teri dari pengoperasian bagan apung rata-rata sebesar 29,87 ton/tahun. Selanjutnya dikatakan pula bahwa dugaan potensi lestari (MSY) ikan teri sebesar 30,82 ton per tahun pada penelitian tahun 2010 .

Sumberdaya ikan di perairan biasanya hadir bila kondisi lingkungan perairan sesuai dengan hidupnya. Ikan teri (Stolephorus sp) juga demikan. Beberapa penelitian menunjukan bahwa parameter osenaografi seperti klorofil-a, suhu permukaan laut, salinitas dll dapat dijadikan sebagai indikator potensial hadirnya sumberdaya jenis ikan ini.

Pengoperasian bagan perahu umumnya dilakukan pada malam hari dengan tujuan untuk meningkatkan efektifitas kegiatan penangkapan. Pada malam hari kondisi cahaya menjadi minim sehingga dapat meminimalkan tingkat penyebaran ikan yang bersifat fototaksis positif di perairan. Biasanya kondisi perairan menjadi pertimbangan nelayan dalam mengoperasikan alat tangkap ini dan bahan kajian ilmiah yang menarik untuk diteliti.

Penelitian ini bertujuan untuk mengetahui dampak dinamika parameter 
oseanografi terhadap hasil tangkapan Bagan Perahu di Teluk Dodingga Kabupaten Halmahera Barat. Manfaat penelitian ini adalah sebagai gambaran informasi bagi nelayan tentang kondisi perairan Teluk Dodinga dalam rangka mendesain manajemen waktu dan hasil tangkapan yang lebih baik.

\section{METODE PENELITIAN}

\section{Waktu dan Tempat}

Penelitian ini dilaksanakan pada bulan November 2016 hingga Januari 2017 di perairan Teluk Dodingga Kabupaten Halmahera Barat (Gambar $1)$.

\section{Alat dan Bahan}

Peralatan penelitian yang digunakan adalah GPS, Handheld Refrektometer, thermometer air, sacchi disk, layangan arus, anemometer tangan, kamera digital dan alat tulis menulis, sedangkan bahan yang digunakan dalam penelitian ini adalah hasil tangkapan Bagan Perahu.

\section{Pengambilan Data}

Pengumpulan data lapangan dilakukan secara langsung/in situ sebanyak 44 kali(2 periode operasi) dengan mengikuti kegiatan penangkapan yang dilakukan oleh nelayan bagan perahu. Data insitu yang diambil meliputi data oseanografi (suhu, salinitas, kecepatan arus, kecepatan angin, kecerahandan data hasil tangkapan ikan teri. Untuk menghindari kesalahan maka setiap pengambilan data parameter oseanografi diulang 2 kali. Hasil tangkapan yang diambil adalah dari 4 buah bagan perahu yang beroperasi pada wilayah perairan ini. Hasil tangkapan ikan teri selanjutnya didentifikasi menurut Peristiwadi (2006).

\section{Analisi Data}

Kegiatan analisis data menggunakan piranti lunak SPSS Versi 20 dengan metode step wise dan visualisasi hasil secara desktriptif menggunakan Microsoft Excel 2010. Semua parameter oseanografi yang diambil kemudian dirata-ratakan baru dianalisis

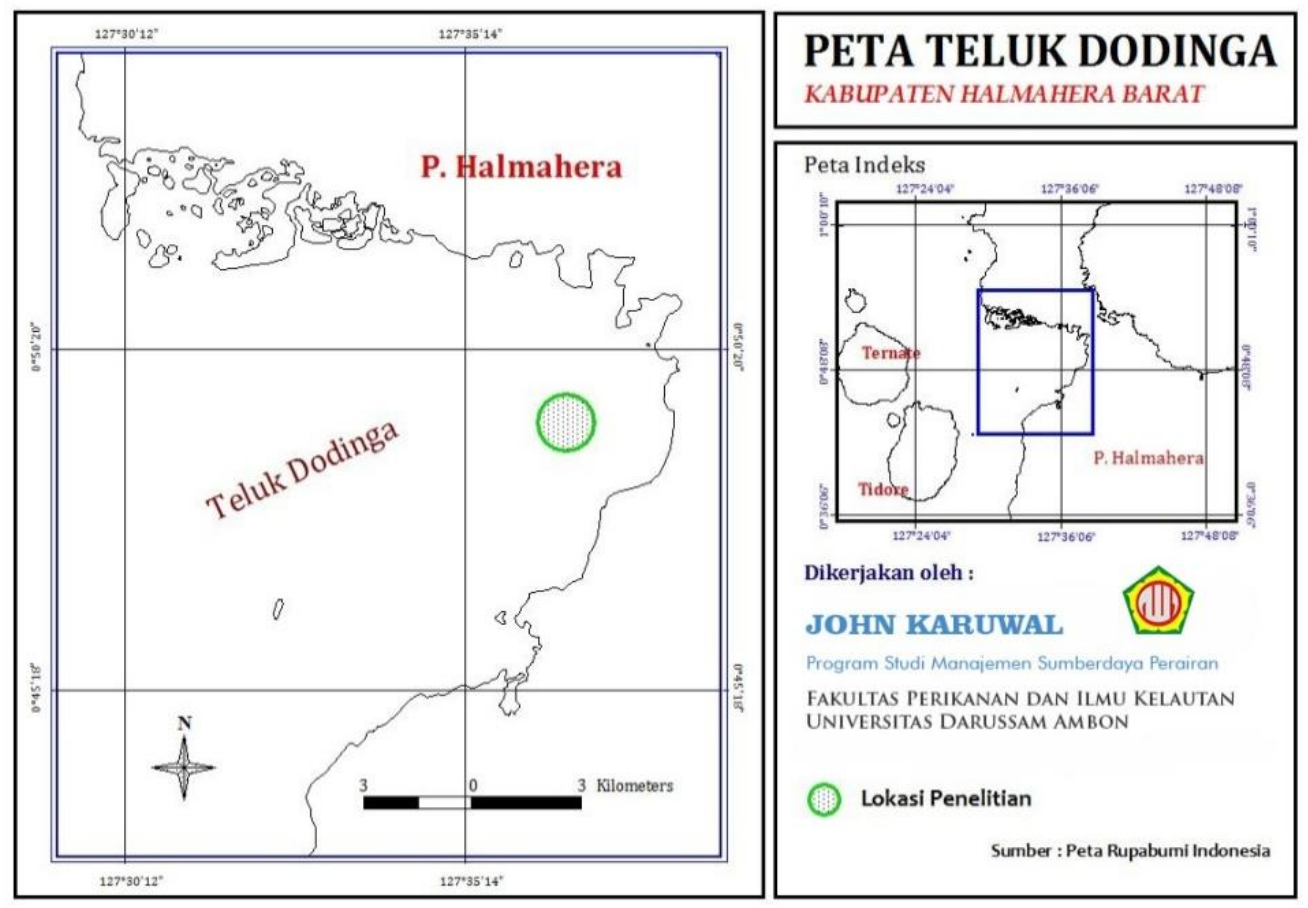

Gambar 1. Lokasi Penelitian. 
Parameter Oseanografi dan komposisi hasil tangakapan

Parameter Oseanografi dan komposisi hasil tangkapan bagan diolah secara deskriptif dan dipaparkan dalam bentuk tabel dan grafik. Gaspersz, 1991 menyatakan bahwa data dapat dikelompokkan ke dalam bentuk sebaran frekuensi melalui penentuan selang dan lebar kelas dengan menggunakan formula:

$$
K=1+3,32 \cdot \log (n)
$$

Range = nilai max-nilai minimum

$I \quad=$ Range $/ K$

Ket $: \mathrm{K}=$ jumlah kelas, $\mathrm{n}=$ Jumlah data, $\mathrm{I}=$ lebar kelas

\section{Hubungan Parameter Oseanografi} dengan Hasil tangkapan Bagan Perahu

Bagan perahu adalah alat tangkap yang operasinya bersifat mobile (berpindah-pindah) dan hasil tangkapannya sangat bergantung pada kondisi oseanografi perairan seperti suhu, klorofil-a, kecepatan arus dan kecerahan. Untuk membuktikan hal ini maka parameter oseanografi tersebut diuji dengan menggunakan analisis regresi linear berganda. Asumsi yang digunakan dalam penelitian ini adalah hasil tangkapan terdistribusi secara merata di perairan dan parameter oseanografi tidak berkaitan satu dengan lainnya. Persamaan matematis analisis regresi linear berganda dengan 4 peubah bebas menurut Steel dan Torrie, 1993 sebagai berikut :

$$
\begin{gathered}
\hat{\mathrm{y}}=a+b_{1} x_{1}+b_{2} x_{2}+b_{3} x_{3}+b_{4} x_{4}+ \\
b_{5} x_{5}+\mathrm{e}
\end{gathered}
$$

dimana :

$\hat{\mathrm{y}}=$ Total hasil tangkapan bagan perahu

$a=$ Koefisien potongan (Konstanta)

$b_{1}=$ Koefisien regresi suhu

$b_{2}=$ Koefisien regresi klorofil-a

$b_{3}=$ Koefisien regresi kecerahan

$b_{4}=$ Koefisien regresi kecepatan arus

$b_{5}=$ Koefisien regresi salinitas
$x_{1}=\operatorname{Suhu}\left({ }^{\circ} \mathrm{C}\right)$

$x_{2}=$ klorofil-a $(\mathrm{m} /$ liter $)$

$x_{3}=$ Kecerahan $(\mathrm{m})$

$x_{4}=$ Kecepatan Arus (ms-1)

$x_{5}=$ Salinitas $(\%)$

$e=$ Standar Error

Dilakukan pula Uji Normalitas Data (Kolmogorov-Smimov Test), Uji Multikolinieritas, Analisis Varians (Uji $F)$ dan Analisis Koefisien Regresi (Uji t)

\section{HASIL DAN PEMBAHASAN}

\section{Pengoperasian Bagan Perahu Di Teluk Dodinga}

Operasi penangkapan bagan perahu di perairan Teluk Dodinga umumnya dimulai pada saat matahari mulai tenggelam. Metode pengoperasian bagan diawali dengan penurunan jaring sampai kedalaman yang diinginkan. Selanjutnya lampu mulai dinyalakan untuk menarik perhatian ikan agar berkumpul di bawah sinar lampu atau di sekitar bagan. Pengangkatan jaring dilakukan apabila ikan yang terkumpul sudah cukup banyak dan keadaan ikanikan tersebut cukup tenang. Jaring diangkat sampai berada di atas permukaan air dan hasil tangkapan diambil dengan menggunakan serok.

Pengoperasian bagan tersebut menggunakan atraktor cahaya (light fishing), sehingga alat ini tidaklah efesien apabila digunakan pada saat bulan purnama. Pada bulan purnama, nelayan bagan tidak melakukan operasi penangkapan. Penangkapan ikan menggunakan alat tangkap bagan perahu di Teluk Dodinga hanya dilakukan pada malam hari, terutama pada saat bulan gelap dengan menggunakan lampu sebagai alat bantu penangkapan. Ada beberapa tahapan dalam melakukan kegiatan penangkapan menggunakan bagan perahu di Teluk Dodinga, yaitu : Persiapan menuju fishing ground, Pengumpulan ikan, Proses penurunan jaring (Setting), Perendaman jaring (Soaking), Pengangkatan jaring (Hauling), Brailing dan Penyortiran ikan. 


\section{Parameter Oseanografi di Lokasi Penelitian}

Pengamatan terhadap parame-ter osenografi bagan perahu di teluk Dodinga dilaksanakan selama 44 hari pengamatan yang terbagi atas 2 periode operasi penangkapan. Periode I berlangsung pada tanggal 20 November hingga 20 Desember 2016 selama 25 hari pengamatan. Periode 2 berlangsung pada tanggal 21 Desember 2016 hingga 10 Januari 2017 selama 21 hari pengamatan. Namun hanya akumulasi 44 buah data yang dipakai dari 2 periode pengambilan data parameter SPL, salinitas, kecerahan, kecepatan angin dan kecepatan arus secara in situ yang dapat dipaparkan. Gambaran kondisi parameter-parameter tersebut sebagai berikut.

\section{Suhu Permukaan Laut}

Suhu termasuk salah satu faktor yang amat penting bagi kehidupan organisme di lautan. karena suhu mempengaruhi baik aktivitas metabolisme maupun perkembangbiakan organisme-organisme tersebut. Hasil pengamatan terlihat bahwa kisaran suhu rata-rata selama penelitian di perairan Teluk Dodinga cenderung berfluktuasi dengan nilai kisaran suhu berkisar antara $23-29^{\circ} \mathrm{C}$.Suhu terendah yang diukur pada saat setting (penurunan jaring) berada pada nilai $23{ }^{\circ} \mathrm{C}$ sedangkan nilai tertinggi adalah $28.5^{\circ} \mathrm{C}$. sedangkan suhu terendah yang diukur pada saat hauling berada pada nilai $23{ }^{\circ} \mathrm{C}$ dan suhu tertinggi adalah $29{ }^{\circ} \mathrm{C}$ (Gambar 2). Sedangkan suhu rata-rata perairan adalah sebesar $26-26,5^{\circ} \mathrm{C}$.

Kondisi suhu permukaan perairan teluk Dodinga yang berdinamika sepanjang penelitian diduga disebabkan kondisi meteorologi (curah hujan) dan adanya masukan dari darat. Alwi, 2014 et al., menemukan bahwa suhu permukaan laut rata-rata di teluk Dodinga pada bulan Januari hingga Maret berkisan antara 27,7 hingga $28,7{ }^{\circ} \mathrm{C}$. Sedangkan penelitian Wantasen dan Tamrin, 2012 menemukan bahwa suhu perairan di Teluk Dodinga berkisar antara sebesar $28,3-34,4{ }^{\circ} \mathrm{C}$. Ada 3 buah sungai yang bermuara di teluk ini, sehingga diduga turut memberikan kontribusi terhadap suhu perairan berupa pencampuran massa air tawar dengan air laut. Hutabarat dan Evans, 2008 menyatakan bahwa suhu permukaan laut juga dipengaruhi oleh pemanasan sinar matahari yang merambat melalui lapisan atmosfir dan perbedaan sudut datang sinar matahari ketika atmosfir mencapai permukaan bumi. Perairan teluk Dodingan berhubungan langsung dengan perairan laut Maluku sehingga diduga ada pengaruh juga dari laut Maluku. Hasil Penelitian Haikal et al., 2012 menunjukan bahwa suhu permukaan laut di laut Maluku pada 0 meter berkisar antara $27,70-28.89^{\circ} \mathrm{C}$ dengan rata-rata $28.31^{\circ} \mathrm{C}$.

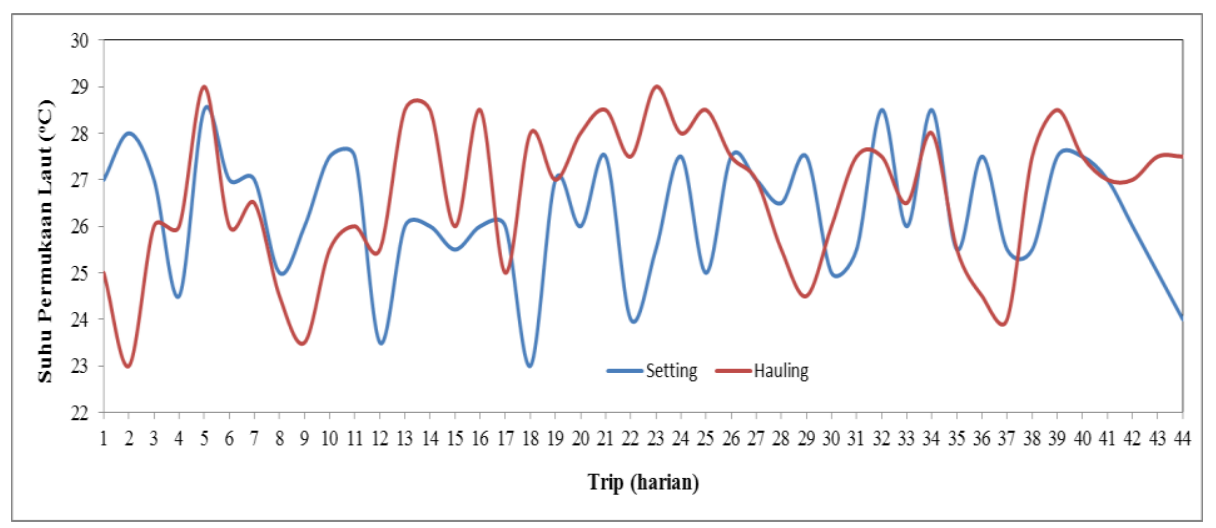

Gambar 2. Sebaran Rata-rata Suhu Permukaan Laut Saat Setting dan Hauling 


\section{Salinitas}

Kondisi salinitas di perairan Teluk Dodinga dapat dilihat pada Gambar 3. Berdasarkan Gambar tersebut, diperoleh kisaran salinitas rata-rata di perairan Teluk Dodinga berkisar antara 25 - 31 ppt pada saat saat seting (penurunan jaring) sedangkan pada saat hauling (pengangkatan jaring) berkisar antara 25 - 30,5 ppt. Rata-rata salinitas perairan ini juga berkisar antara $27-28$ ppt. Kondisi salinitas perairan teluk Dodinga yang memiliki retangan yang lebar diduga dipengaruhi oleh adanya masukan air tawar dari darat. Kalangi et al., 2013 menyatakan bahwa salinitas suatu perairan secara horizontal di pengaruhi oleh pola sirkulasi air, penguapan, curah hujan dan masukan dari air sungai. Lebih lanjut dikatakan bawah pengaruh air sungai membuat variasi salinitas di perairan pantai lebih besar dibandingkan dengan laut lepas. Kisaran salinitas di perairan pantai dapat berkisar antara 0-33 ppt tergantung dari volume air sungai yang dialirkan masuk ke teluk. Hasil penelitian Wantasen dan Tamrin, 2012 mendapatkan bawah salinitas pesisir teluk Dodinga ada pada kisaran 29 - 35 ppt.

\section{Kecerahan}

Kecerahan merupakan ukuran transparansi perairan dan pengukuran penetrasi cahaya di dalam kolom air yang biasanya dilakukan dengan menggunakan lempengan/kepingan Secchi disk. Hasil penelitian menunjukan bahwa tingkat kecerahan perairan Teluk Dodinga berkisar antara 7.5 13.25 m dapat dilihat pada Gambar 5 .

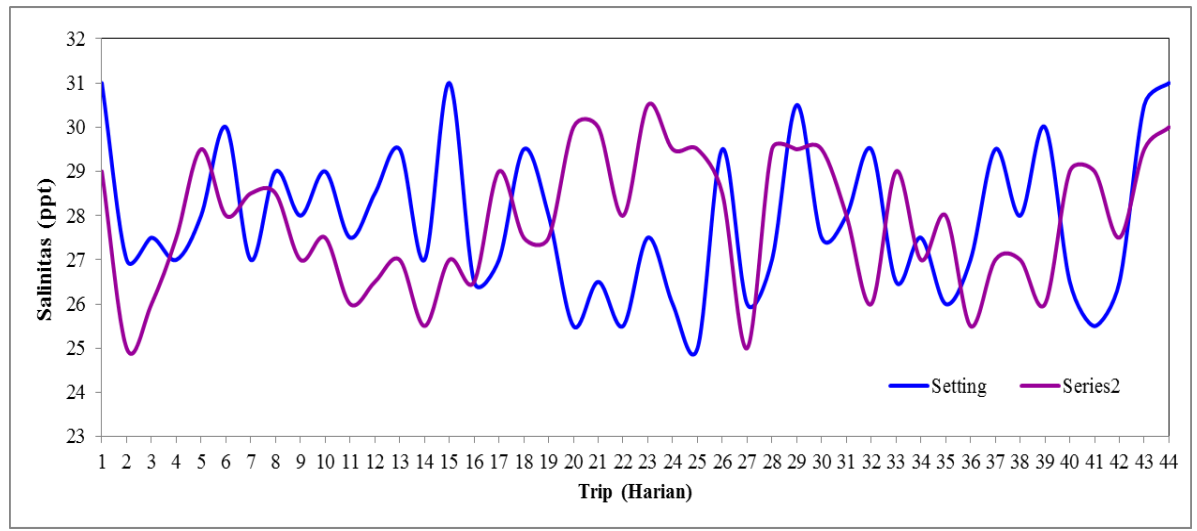

Gambar 3. Sebaran rata-rata Salinitas Setting dan Hauling

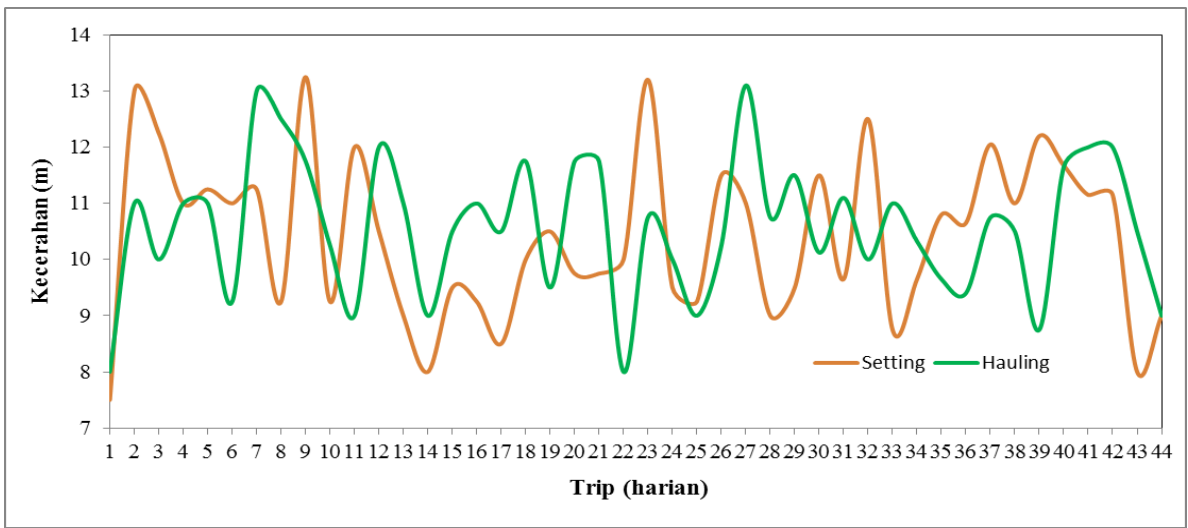

Gambar 5. Sebaran Rata-rata Kecerahan Perairan Teluk Dodinga 
Gambar 5 menunjukan bahwa sebaran kecerahan selama penelitian di perairan Teluk Dodinga di lokasi pengoperasian bagan berada pada kisaran kedalaman 7.5 - 13.25 meter di mana pada saat setting. Sedangkan pada saat hauling berkisar antara $8-13,1$ meter. Rata-rata kecerahan berkisar antara 8 - 10 meter. Perbedaan rentangan nilai kecerahan diduga berhubungan dengan penetrasi cahaya yang masuk ke laut dan periode hari bulan di langit. Biasanya pengoperasin bagan selalu dilakukan pada pencahayaan yang minim baik dari alam maupun buatan.Cahaya yang masuk ke dalam air akan mengalami pereduksian yang jauh lebih besar bila dibandingkan dalam udara. Hal tersebut terutama disebabkan oleh adanya penyerapan (absorbsi), pemantulan (refleksi) dan hamburan (scattering).

Menurut Wahyono dan Prabowo (2009) cahaya menjadi beberapa bentuk energi sehingga cahaya tersebut akan cepat sekali tereduksi sejalan dengan semakin dalam suatu perairan. Pembalikan dan pencemaran cahaya yang disebabkan oleh berbagai partikel dalam air dan keadaan cuaca dan gelombang banayak memberikan andil pada pereduksian cahaya yang diterima air tersebut. Lebih lanjut dikemukakan bahwa tingkat kecerahan sangat dipengaruhi oleh intensitas cahaya yang masuk ke dalam perairan dan tingkat sedimentasi di perairan tersebut.

\section{Kecepatan arus}

Menurut Tanto et al., 2017, di perairan dangkal (kawasan pantai), arus laut dapat dibangkitkan oleh gelombang laut, pasang surut laut atau sampai tingkat tertentu oleh angin. Sedangkan menurut Dahuri et al., 2013, di perairan sempit dan semi tertutup seperti selat dan teluk, pasut merupakan gaya penggerak utama sirkulasi massa airnya. Hasil penelitian mendapatkan kondisi arus di perairan Teluk Dodinga pada pengoperasian bagan perahu. dapat dilihat pada Gambar 6.

Gambar 6. menunjukan bahwa sebaran kecepatan arus rata-rata selama penelitian di perairan Teluk Dodinga di lokasi pengoperasian bagan sebesar 0,19 - 0,95 m/detik di mana pada pada saat setting dan pada saat hauling berkisar antara $0,11-0,97 \mathrm{~m} /$ detik. Rata-rata kecepatan arus berkisar antara 0,45 0,55 meter/detik. Berfluktuasinya nilai kecepatan arus rata-rata selama penelitian diduga karena kondisi meteorologi (angin dan tekanan) dan periode hari bulan yang cenderung berubah seiring waktu. Norman et al., 2012 menyatakan bahwa arus permukaan laut terutama disebabkan oleh adanya angin yang bertiup di atasnya, bentuk dasar perairan, letak geografi dan tekanan udara. Akibatnya arus yang mengalir di permukaan lautan merupakan hasil kerja gabungan faktorfaktor tersebut. Penelitian Alwi, 2014 et al.. Menemukan bahwa kondisi kecepata arus di teluk Dodingan berkisar 0.02 hingga 0,22 meter/detik selama bulan janurai hingga Maret. Sedangkan penelitian Wantasen dan Tamrin, 2012, menemukan kecepatan arus di pesisir teluk Dodingan adalah sebesar2,7 - 35 meter/detik.

\section{Kecepatan angin}

Angin merupakan salah satu unsur iklim yang mempunyai peranan penting dalam interaksi antara laut dan atmsofer sehingga mendapat perhatian tidak hanya dalam penelitian meteorologi saja tetapi juga dalam penelitian kelautan. Transfer energi dari angin permukaan ke laut akan menyebabkan terjadinya gelombang laut dan arus permukaan laut. Selain sebagai pembangkit gelombang laut dan arus permukaan laut, angin dapat menyebabkan terjadinya proses upwelling. Sebaran kecepatan angin di Teluk Dodinga dapat dilihat pada Gambar 7. 


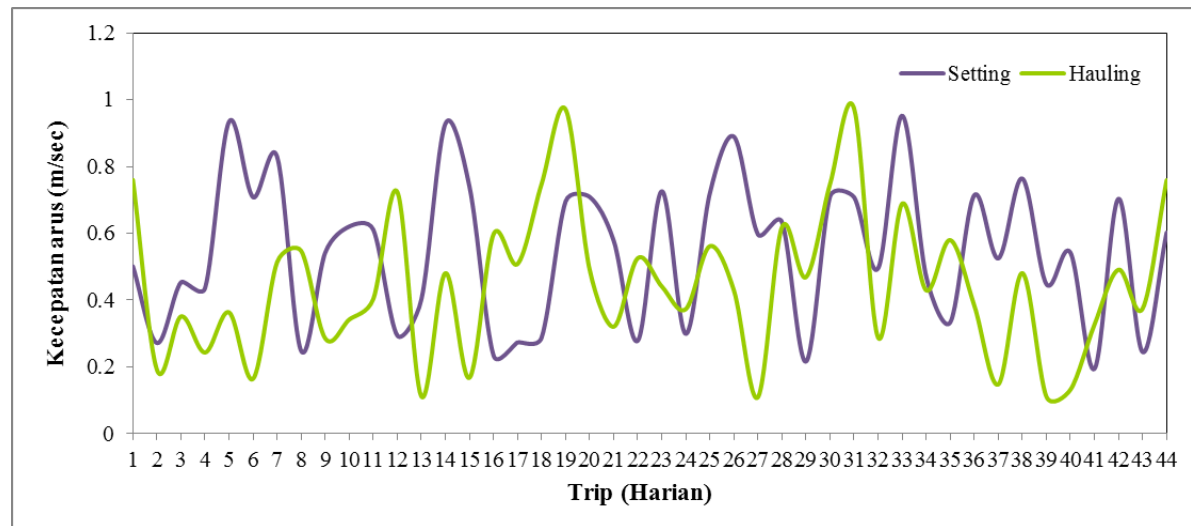

Gambar 6. Kecepatan Rata-rata Arus Perairan Teluk Dodinga

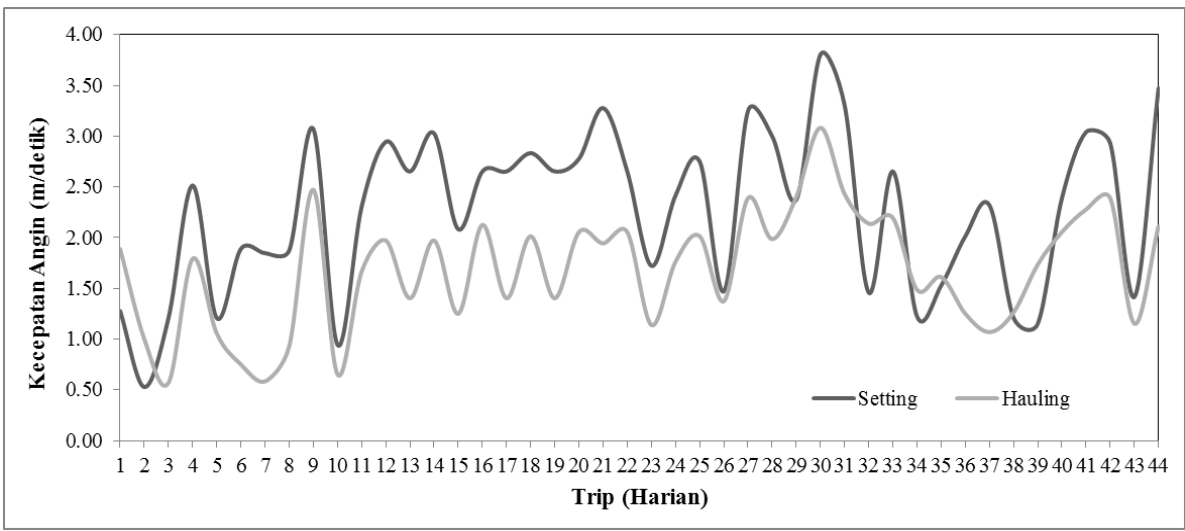

Gambar 7. Kecepatan Angin Rata-Rata Perairan Teluk Dodinga

Gambar 7 menunjukan bahwa kecepatan angin saat penelitian diperairan Teluk Dodinga sebesar 0.528 - $3.806 \mathrm{~m} /$ detik dimana pada saat setting, sedangkapn pada saat hauling yaitu $0.569-3,083 \mathrm{~m} /$ detik.Kecepatan rata-rata angin di perairan ini selama penelitian sebesar 1,688 - 2,268 meter/det. Pariwono, 1998 menyatakan bahwa di sebahagian besar perairan angin dan pasang surut menjadi faktor utama penyebab munculnya arus yang kuat yang sangat mempengaruhi aktivitas melaut. Dikatakan lebih lanjut bahwa kondisi arus permukaan pada sebuah teluk ditentukan oleh arah dan kecepatan angin yang berhembus dan lamanya hembusan. Angin juga merupakan pemicu terjadinya gelombang laut.

\section{Hasil Tangkapan Ikan Teri}

Ikan teri merupakan ikan target dari perikanan bagan perahu di teluk
Dodinga. Hasil tangkapan ikan teri dari 4 bagan perahu di perairan teluk Dodinga selama penelitian adalah sebesar 17.787.74 kg basah (Gambar 8).

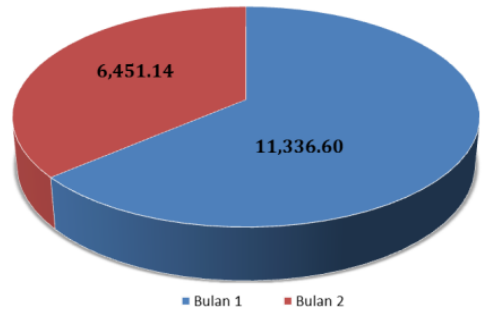

Gambar 8 . Hasil Tangkapan Ikan Teri Selama Penelitian

Pengamatan lebih lanjut mendapatkan bahwa hasil tangkapan ini pada periode penangkapan 1 sebesar $11.336 .60 \mathrm{~kg}$ lebih besar dari pada periode 2 sebesar $6.451 .14 \mathrm{~kg}$ basah. Kondisi ini terjadi karena durasi operasi periode pertama lebih panjang 6 hari dibandingkan dengan periode kedua. Selama penelitian berlangsung, terjadi perubahan cuaca dan kondisi perairan 
seperti gelombang atau arus yang terlampau kencang sehingga ada kegiatan operasi penangkapan yang tidak memberikan hasil tangkapan.

Kondisi hasil tangkapan ini lebih jelas terlihat pada distribusi hasil tangkapan harian ikan teri selama penelitian (Gambar 9).

Hasil tangkapan harian cenderung berfluktuasi selama periode $1-2$ (Gambar 9). Hasil tangkapan terbanyak terjadi pada tanggal 25 November 2016 pada periode 1 dengan hasil tangkapan yaitu 665,16 kg sedangkan hasil tangkapan paling rendah terjadi pada tanggal 4 Januari 2017 terdapat pada periode 2 yaitu sebanyak $222,68 \mathrm{~kg}$ secara umum dapat digambarkan bahwa ikan teri yang tertangkap pada bagan perahu berfluktuasi sepanjang waktu penelitian. Hal ini pun terjadi pada penelitian yang dikerjakan oleh Safruddin et al., 2014 di perairan pesisir Spermonde, Pangkep yang mendapatkan hasil tangkapan teri yang berbeda pada bulan April dan Mei.

\section{Hubungan Antara Hasil Tangkapan dengan Parameter Oseanografi}

Pengujian hubungan antara parameter oseanografi terhadap hasil tangkapan ikan teri pada penelitian ini hanya menggunakan parameter in situ yaitu suhu permukaan laut. salinitas. kecerahan. kecepatan arus dan kecepatan angin.

\section{Uji Normalitas Data}

Uji Normalitas data dilakukan untuk melihat apakah data berasal dari populasi yang sama dan apakah data tersebut juga memiliki varian-varian yang sama pula. Data dikatakan berdistribusi normal jika data memusat pada nilai rata-rata median. Kriteria data berdistribusi secara normal apabila data akan menyebar disekitar garis diagonal dan pola distribusinya akan membentuk lonceng.

Hasil uji Normalitas dengan mengunakan uji statistik liliefros (Kolmogorof-Smirnof Test) untuk tiap parameter oseanografi dari keempat parameter tersebut berdistribusi normal memiliki nilai signifikansi sebesar 0.725 lebih besar dari nilai $\alpha=0.05$. Sedangkan dengan grafik probability dapat diketahui bahwa data menyebar mengikuti arah garis diagonal.

\section{Multikolinearitas}

Multikoliniritas adalah keadaan dimana antara dua varaiabel independen atau lebih pada model regresi terjadi hubungan linier yang sempurna atau mendekati sempurna.

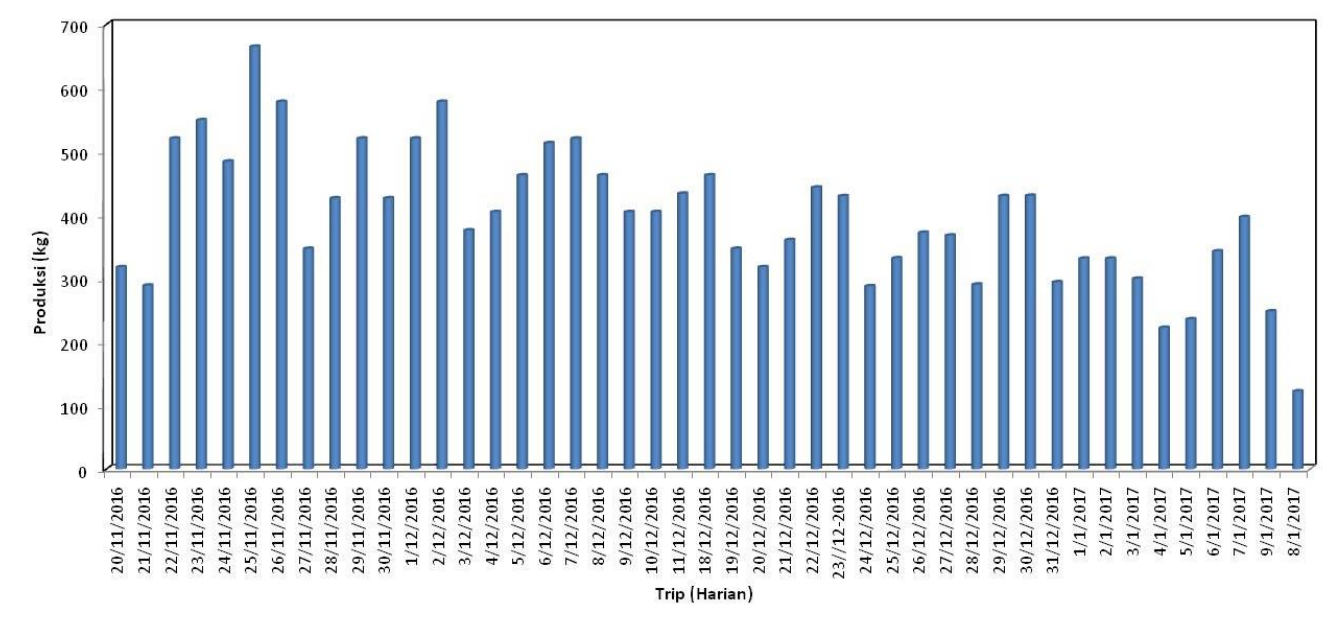

Gambar 9. Produksi Tangkapan Harian Ikan Teri Selama Penelitian. 
Untuk melihat ada tidanya masalah multikolinieritas yaitu dengan melihat nilai Tolerance dan VIF maka semakin mendekati terjadinya masalah multikolinieritas. dalam kebanyakan penelitian menyebutkan bahwa jika nilai Tolerance lebih dari 0.1 dan VIF kurang dari 10 maka terjadi multikolinieritas (Priyatno. 2009). Hasil uji regresi berganda dengan metode stepwise dapat lihat pada tabel Coefficients pada kolom Collinearity Statistics dapat diketahui bahwa nilai Tolerance dari keempat variabel independen sebesar 1.000 dan nilai VIF sebesar 1.00 kurang dari 10. jadi dapat disimpulkan bahwa dalam model regresi tidak terjadi masalah multikolinieritas.

\section{Uji F}

Uji statistik regresi linier berganda digunakan untuk menguji signifikansi atau ada tidaknya hubungan lebih dari dua variabel melalui koefisien regresinya. Uji $\mathrm{F}$ bertujuan untuk melihat apakah ada pengaruh yang diberikan oleh faktor Oseanografi (SPL. kecerahan. kecepatan arus dan kecepatan angin) terhadap nilai hasil tangkapan teri (Stolehorus spp). Pengaruh yang dimaksud dalam uji $\mathrm{F}$ ini adalah pengaruh yang diberikan secara bersamasama oleh variabel $\mathrm{X}$ (parameter Oseanografi) terhadap satu variabel $\mathrm{Y}$ (hasil tangkapan teri Stolehorus spp).

Hasil uji F (Tabel 2) dengan metode stepwise didapati nilai $\mathrm{F}_{\text {hitung }}$ sebesar 9.058 dengan tingkat signifikan 0.004 ini berarti bahwa kelima faktor oseanografi secara bersama-sama berpengaruh nyata terhadap hasil tangkapan teri (Stolehorus spp).

\section{Uji $t$}

Jika uji F dilakukan untuk melihat pengaruh faktor oseanografi secara serentak terhadap hasil tangkapan ikan teri (Stolehorus spp). maka uji $\mathrm{t}$ dilakukan untuk melihat pengaruh faktor oseanografi tersebut terhadap hasil tangkapan teri (Stolehorus spp) secara individual. Analisis uji t ini dengan mengunakan metode stepwise. dimana parameter oseanografi dimasukan sebagai variabel bebas $(\mathrm{X})$.

Tabel 2. Hasil Uji F

\begin{tabular}{llrrrrr}
\multicolumn{8}{c}{ ANOVA $^{\mathbf{a}}$} \\
\hline & Model & Sum of Squares & df & Mean Square & \multicolumn{1}{c}{ F } & \multicolumn{1}{c}{ Sig. } \\
\hline \multirow{3}{*}{1} & Regression & 76627.048 & 1 & 76627.048 & 9.058 & $.004^{\mathrm{b}}$ \\
& Residual & 355296.146 & 42 & 8459.432 & & \\
& Total & 431923.194 & 43 & & & \\
\hline
\end{tabular}

a. Dependent Variable: Hasil Tangkapan

b. Predictors: (Constant). Kecepatan Angin

Tabel 3. Hasil Uji t

\begin{tabular}{|c|c|c|c|c|c|c|c|c|}
\hline \multicolumn{9}{|c|}{ Coefficients $^{\mathrm{a}}$} \\
\hline & \multirow[t]{2}{*}{ Model } & \multicolumn{2}{|c|}{$\begin{array}{l}\text { Unstandardized } \\
\text { Coefficients }\end{array}$} & \multirow{2}{*}{$\begin{array}{c}\begin{array}{c}\text { Standardize } \\
\text { d } \\
\text { Coefficients }\end{array} \\
\text { Beta }\end{array}$} & \multirow[t]{2}{*}{$\mathbf{t}$} & \multirow[t]{2}{*}{ Sig. } & \multicolumn{2}{|c|}{$\begin{array}{c}\text { Collinearity } \\
\text { Statistics }\end{array}$} \\
\hline & & B & Std. Error & & & & Tolerance & VIF \\
\hline \multirow{2}{*}{1} & (Constant & 526.666 & 42.967 & & $\begin{array}{r}12.25 \\
7\end{array}$ & .000 & & \\
\hline & $\begin{array}{l}\text { Kecepata } \\
\text { n Angin }\end{array}$ & -72.513 & 24.093 & -.421 & -3.010 & .004 & 1.000 & 1.000 \\
\hline
\end{tabular}

a. Dependent Variable: Hasil Tangkapan 
Hasil uji t (Tabel 3). menunjukan bahwa faktor oseanografi yang berpengaruh nyata terhadap hasil tangkapan teri (Stolehorus spp) yaitu kecepatan angin sebesar -3.010 dengan nilai signifikansi $0.004 \quad(<\alpha=0.05)$. Faktor oseanografi lain secara individu tidak berpengaruh nyata terhadap hasil dengan nilai signifikansi lebih besar dari $\alpha$ adalah 0.005 dan dikeluarkan dari model (Tabel 3).

Selanjutnya didapati nilai $\mathrm{R}$ square atau koefisien korelasi sebesar 0.177 dan koefesien determinasi $(\mathrm{R})=$ 0.421 . Nilai ini menunjukan bahwa secara keseluruhan parameter kecepatan angin memberikan kontribusi $42.1 \%$ bagi hasil Tangkapan teri di perairan Teluk Dodinga. sehingga model regresi yang digunakan untuk menjelaskan hubungan parameter oseanografi utama dengan hasil tangkapan teri di perairan Teluk Dodinga adalah $\widehat{\boldsymbol{y}}=\mathbf{5 2 6 . 6 6 6}$ 72.513 $\boldsymbol{X}_{\boldsymbol{I}}+\boldsymbol{e}$, dimana $\mathrm{X}_{1}$ adalah kecepatan angin.Secara umum diketahui bahwa kecepatan angin dalam operasi penangkapan bukan merupakan faktor utama dinamika hasil tangkapan, namun angin merupakan faktor yang memicu terjadinya pergerakan massa air di suatu perairan yang tentunya membawa nutrient bagi organisme perairan. Analisis lanjutan terhadap persamaan ini yang digambarkan dalam digram pencar/scatter (Gambar 10) mendapatkan juga nilai koefisien determinasi $\left(\mathrm{R}^{2}\right)$ yang kecil sebesar 0.2031 atau angin hanya memberikan kontribusi sebesar 20\% untuk hasil tangkapan ikan teri dari 5 parameter fisik oseanografi yang diteliti.

Tabel 4. Faktor Oseanografi Yang Dikeluarkan Dari Model Persamaan

Excluded Variables ${ }^{\mathrm{a}}$

\begin{tabular}{|c|c|c|c|c|c|c|c|c|}
\hline & \multirow[b]{2}{*}{ Model } & \multirow[b]{2}{*}{ Beta In } & \multirow[b]{2}{*}{$\mathbf{t}$} & \multirow[b]{2}{*}{ Sig. } & \multirow[b]{2}{*}{$\begin{array}{c}\text { Partial } \\
\text { Correlatio } \\
\mathbf{n}\end{array}$} & \multicolumn{3}{|c|}{ Collinearity Statistics } \\
\hline & & & & & & $\begin{array}{c}\text { Toleranc } \\
\text { e }\end{array}$ & VIF & $\begin{array}{c}\text { Minimu } \\
\text { m } \\
\text { Toleranc } \\
\text { e }\end{array}$ \\
\hline \multirow{4}{*}{1} & SPL & $.136^{\mathrm{b}}$ & .957 & .344 & .148 & .978 & 1.022 & .978 \\
\hline & Salinitas & $-.076^{\mathrm{b}}$ & -.534 & .597 & -.083 & .980 & 1.020 & .980 \\
\hline & $\begin{array}{l}\text { Kecepatan } \\
\text { Arus }\end{array}$ & $.074^{\mathrm{b}}$ & .496 & .622 & .077 & .902 & 1.109 & .902 \\
\hline & Kecerahan & $.148^{\mathrm{b}}$ & 1.054 & .298 & .162 & .995 & 1.005 & .995 \\
\hline
\end{tabular}

a. Dependent Variable: Hasil Tangkapan

b. Predictors in the Model: (Constant). Kecepatan Angin

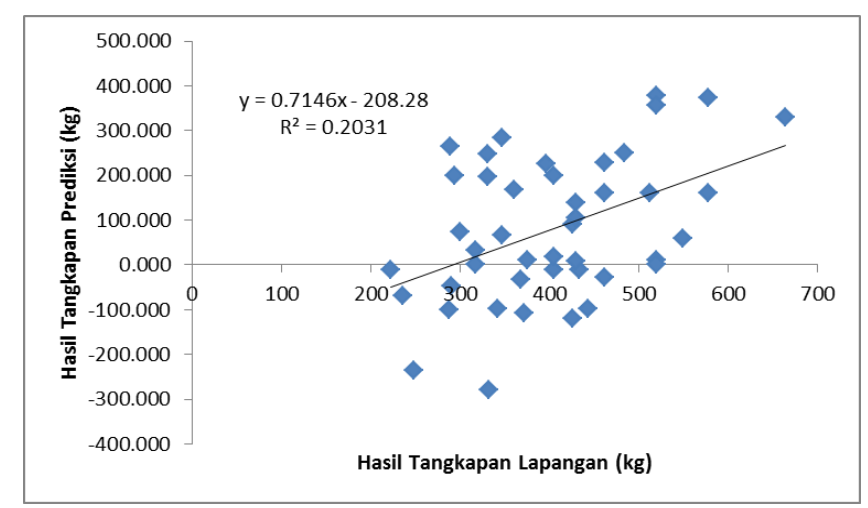

Gambar 10. Grafik Hubungan antara Hasil Tangkapan Lapangan dengan Tangkapan Prediksi. 


\section{Dinamika perubahan Parameter Oseanografi in situ terhadap distribusi Ikan Teri di Teluk Dodinga, Kabupaten Halmahera Barat}

Parameter oseanografi mempunyai peran sangat penting dalam mempelajari distribusi dan kelimpahan sumberdaya ikan. Naik-turunnya nilai dari parameter-parameter ini sangat mempengaruhi kehadiran ikan teri di dalam suatu perairan. Menurut Nyabaken (1992) pada perairan estuari atau teluk memiliki dinamika parameter perairan seperti suhu permukan laut. kecepatan arus dan salinitas yang cenderung berfluktuatif sepanjang musim. Hal ini pun terjadi di perairan teluk Dodinga sehingga diduga memberikan pengaruh terhadap hasil tangkapan ikan teri.Hasil analisis deskriptif terhadap dinamika parameter oseanografi insitu perairan teluk Dodinga tergambar dalam 7 (tujuh) kelas yang divisualisasikan dalam grafik berikut ini.

\section{Dinamika Suhu Permukaan Laut terhadap Hasil Tangkapan Teri}

Pada perairan teluk Dodinga didapati bahwa suhu permukaan laut cenderung berfluktuasi selama penelitian dan membawa dampak terhadap hasil tangkapan teri yang didapat (Gambar 11).

Hasil penelitian menunjukan bahwa hasil tangkapan ikan teri terbanyak pada suhu $26,75-27.69^{\circ} \mathrm{C}$ yaitu sebanyak $4.220 .26 \mathrm{~kg}$ dan terendah pada suhu $23.00-23.93^{\circ} \mathrm{C}$ dan $28.64-$ $29.57^{\circ} \mathrm{C}$ dengan hasil tangkapan masingmasing sebesar $715.16 \mathrm{~kg}$ dan $947.12 \mathrm{~kg}$ pada dua trip penangkapan. Didapati pula bahwa ikan teri pada teluk ini tertangkap pada rentang suhu $24-28$ ${ }^{\circ} \mathrm{C}$. Rentang suhu yang besar ini diduga karena adanya masukan air tawar dari daratan Halmahera oleh 3 buah sungai yang bermuara di teluk ini.Hasil penelitian ini didukung juga oleh pernelitian sebelumnya yang dikerjakan oleh Alwi et al., 2014 yang menemukan bahwa ikan teri tertangkap pada suhu $27,7-28,5^{\circ} \mathrm{C}$ untuk waktu penangkapan Januari hingga Maret. Demikian pun halnya penelitian Safruddin et al., 2016 menemukan bahwa ikan teri tertangkap pada kisaran suhu $29,0-29,5^{\circ} \mathrm{C}$ di perairan Luwuk. Hasil Uji korelasi antara Suhu Permukaan Laut dengan Hasil Tangkapan Ikan Teri mendapatkan nilai sebesar 0.0702. Ini menunjukan bahwa ada hubungan antara suhu permukaan laut dengan hasil tangkapan namun memiliki kareakter yang sangat lemah (mendekati nol).

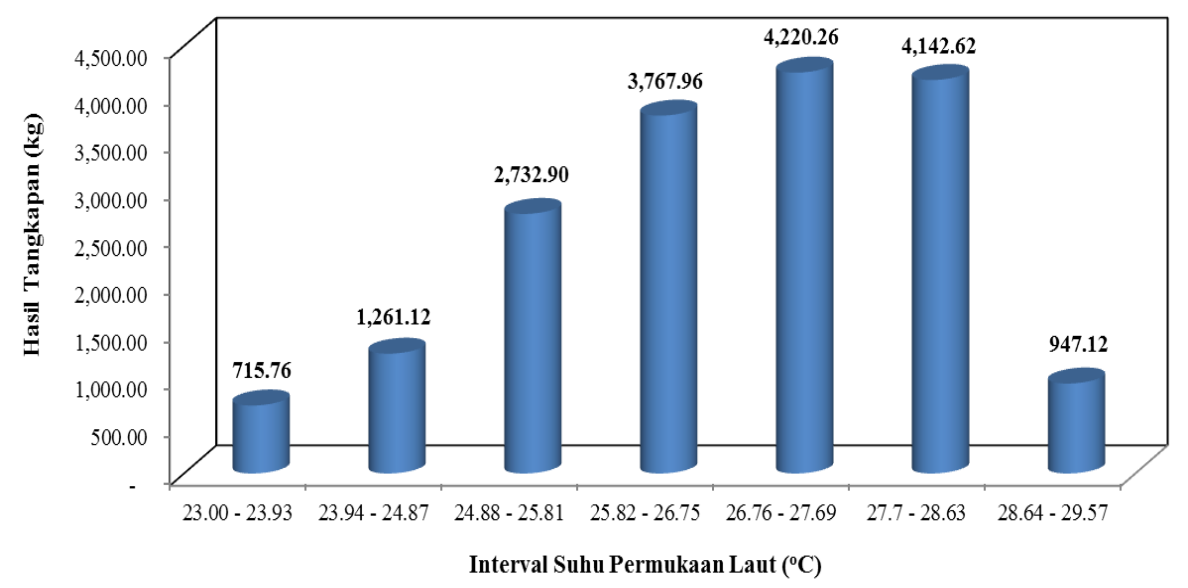

Gambar 11. Grafik Hubungan Suhu Permukaan Laut dengan Hasil Tangkapan Teri 


\section{Dinamika Salinitas Perairan terhadap Hasil Tangkapan Teri}

Salinitas adalah faktor penting bagi penyebaran organisme perairan laut. Salinitas merupakan salah satu besaran penting dalam sistem ekologi laut. Salinitas berpengaruh terhadap sistem metabolime dari ikan yaitu berperan dalam sistem pertukaran gas maupun cairan dalam tubuh ikan. Hubungan antara dinamika salinitas perairan dengan hasil tangkapan ikan teri di teluk Dodinga digambarkan dalam Gambar 12.

Gambar tersebut menunjukan bahwa hasil tangkapan ikan teri di teluk Dodinga berfluktuatif paling banyak tertangkap pada rentang salinitas 26.71 $27.55 \mathrm{ppt}$ sebanyak $4.899 .56 \mathrm{~kg}$ dari11 trip penangkapan dan terendah pada rentang salinitas 30,12-30,96 ppt dari 1 trip penangkapan.Secara umum terlihat bahwa salinitas yang cocok untuk kehidupan ikan teri di teluk Dodinga adalah pada salinitas $25-30$ ppt. Hal ini juga ditemukan pada penelitian Kusuma et al., 2014 yang menemukan bahwa ikan teri tertangkap pada kisaran salinitas 29-33 ppt di perairan Morodemak. Demikian halnya penelitian Nasution et al., 2015 menemukan bahwa ikan teri di perairan selat Asam, Kabupaten Meranti, Riau hidup pada kisaran salinitas 25 - 31 ppt.

Salinitas perairan berhubungan laju pengenceran yang terjadi di perairan dimanaada air tawar yang masuk dari daratan yang bercampur dengan air laut karena aksi gelombang dan arus. Nilai salinitas yang rendah ini diduga karena kegiatan operasi penangkapan berada pada wilayah run off sungai-sungai yang bermuara di Teluk Dodinga.

Hasil uji korelasi mendapatkan nilai negatif sebesar -0.1336 . Nilai ini menunjukan bahwa karakteristik hubungan antara salinitas dengan hasil tangkapan teri cukup lemah.

\section{Dinamika Kecepatan Angin terhadap Hasil Tangkapan Teri}

Angin yang berhembus dengan kencang dapat mengakibatkan terjadinya percampuran massa air pada lapisan atas yang mengakibatkan lapisan permukaan air tercampur menjadi lebih rendah. Hubungan antara kecepatan angin dengan hasil tangkapan di Teluk Dodinga dapat dilihat pada Gambar 13.

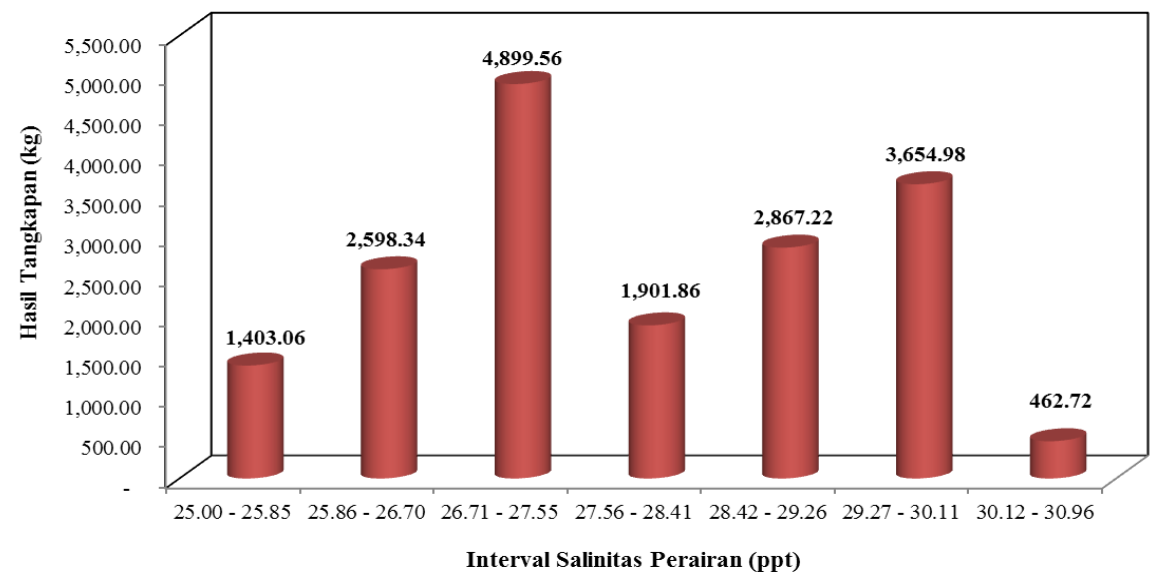

Gambar 12.Grafik Hubungan Salinitas dengan Hasil Tangkapan Teri 


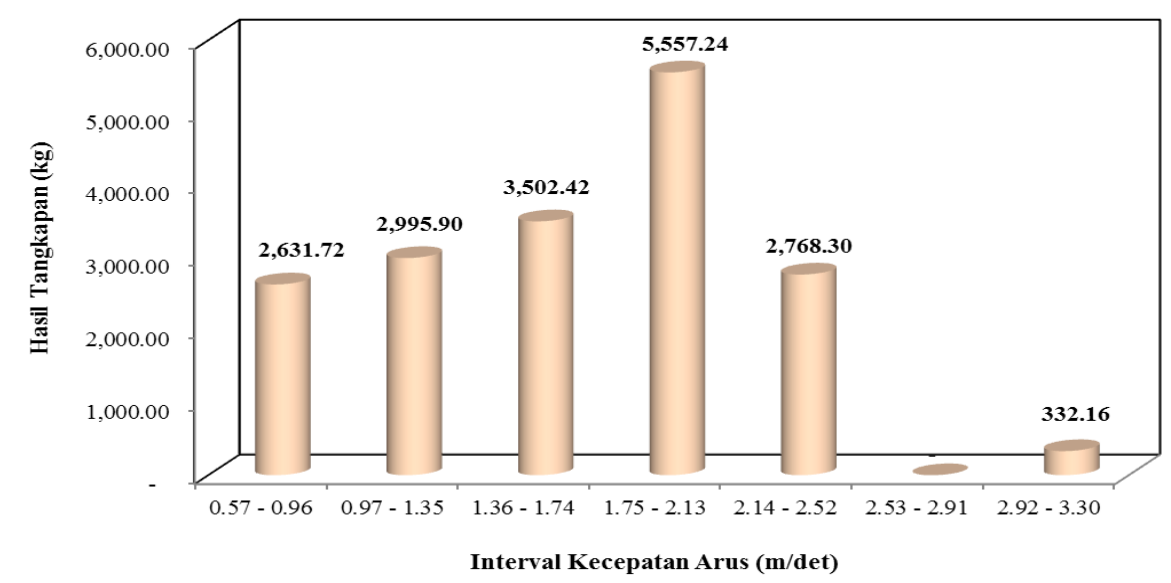

Gambar 13.Grafik Hubungan Kecepatan Angin dengan Hasil Tangkapan Teri

Hasil penelitian menunjukan bahwa hasil tangkapan ikan teri di teluk Dodinga paling banyak tertangkap saat pengukuran kecepatan angin berkisar antara $1.75-2.13 \mathrm{~m} /$ detik dengan hasil tangkapan sebesar $5.379 .64 \mathrm{~kg}$ dari 14 trip penangkapan. Hasil tangkapan terendah ditemukan pada kecepatan angin 2,29 - 3.30 meter/detik sebanyak $332,16 \mathrm{~kg}$ dari 1 trip penangkapan.Secara umum hasil tangkapan ikan teri yang bagus berada pada kondisi kecepatan angin sebesar $0-2,5$ meter/detik. Menurut Steward, 2008, kondisi kecepatan angin yang demikian adalah bernilai 2 pada skala beaufort dengan tiupan yang sepoi lemah dimana angin ini memberikan gejala riak gelombang kecil, masih pendek tetapi tampak puncak mempunyai kenampakan bagai kaca dengan tinggi gelombang 0 0,2 meter. Angin juga berperan terhadap terbentuknya kecepatan arus di suatu perairan. Menurut Nining (2002) pergerakan angin yang menimbulkan terjadinya sirkulasi arus di permukaan laut. Azis (2006) menyatakan bahwa angin cenderung mendorong lapisan air di permukaan laut dalam arah gerakan angin. Tetapi karena pengaruh rotasi bumi atau pengaruh gaya Coriolis, arus tidak bergerak searah dengan arah angin tetapi dibelokan ke arah kanan dari arah angin di belahan bumi utara dan arah kiri di belahan bumi selatan. Selanjutnya dikatakan bahwa Arus yang dibangkitkan angin ini kecepatannya berkurang dengan bertambahnya kedalaman dan arahnya berlawanan dengan arah arus di permukaan. Menurut penelitian Rasyid (2011) menyatakan bahwa pada kecepatan angin sebesar 15 knot $(7,716$ $\mathrm{m} / \mathrm{det}$ ) dari arah barat saat memasuki perairan Spermonde dapat membentuk arus permukaan laut sebesar 0,04 meter per detik dan makin kuat menuju selatan dengan kecepatan 0,30 meter/detik.

Hasil Uji korelasi antara Kecepatan angin dengan Hasil Tangkapan Ikan Teri mendapatkan nilai sebesar 0.4206. Ini menunjukan bahwa kecepatan angin memiliki hubungan dengan hasil tangkapan ikan teri, namun secara tidak langsung.

\section{Dinamika Kecepatan Arus Laut terhadap Hasil Tangkapan Teri}

Arus merupakan salah satu parameter perairan yang telah menjadi patokan nelyan tradisonal dalam mengoperasikan alat tangkap bagan oleh nelayan di perairan teluk Dodinga. Dinamika arus yang terjadi saat penelitian yang berhubungan dengan hasil tangkapan teri dapat dilihat pada Gambar 14. 
Berdasarkan gambar diatas dapat diketahui bahwa hasil tangkapan ikan teri di Teluk Dodinga paling banyak tertangkap saat pengukuran kecepatan arus antara 0,24 - 0,37 meter/detik sebesar 4.254, $42 \mathrm{~kg}$ dari 10 trip penangkapan. Hasil tangkapan terendah ditemukan saat kecepatan arus mencapai 0,91-1,04 meter/detik dengan jumlah trip penangkapan sebanyak 2 trip.Secara umum didapat gambaran bahwa ikan teri tertangkap pada kecepatan arus sebesar $0,1-0,7$ meter/detik. Penelitian Alwi et al., 2014 juga mendapatkan bahwa kondisi arus permukaan di perairan teluk Dodinga berada pada kisaran $0,05-0,22$ meter/detik pada bulan Januari-Maret. Sudirman et al., (2006) menyatakan bahwa kecepatan arus yang dapat ditolelir untuk menurunkan jaring pada pengoperasian bagan rambo di perairan Selat Makassar ialah $0,339 \mathrm{~m} /$ detik untuk arus permukaan dan $0,315 \mathrm{~m} /$ detik untuk arus bawah.

Hasil uji korelasi mendapatkan nilai negatif sebesar -0.0625 . Nilai ini menunjukan bahwa ada hubungan antara salinitas dengan hasil tangkapan teri namun tidak secara langsung.

\section{Dinamika Kecerahan Perairan Terhadap Hasil Tangkapan Teri}

Kecerahan merupakan salah satu faktor oseanografi yang juga sangat berpengaruh terhadap hasil tangkapan ikan di suatu wilayah tertentu. Hal ini disebabkan karena ikan memiliki tingkat sensitivitas yang cukup tinggi terhadap cahaya. Dinamika kecerahan perairan terhadap hasil tangkapan ikan teri di teluk Dodinga dapat dilihat pada Gambar 15.

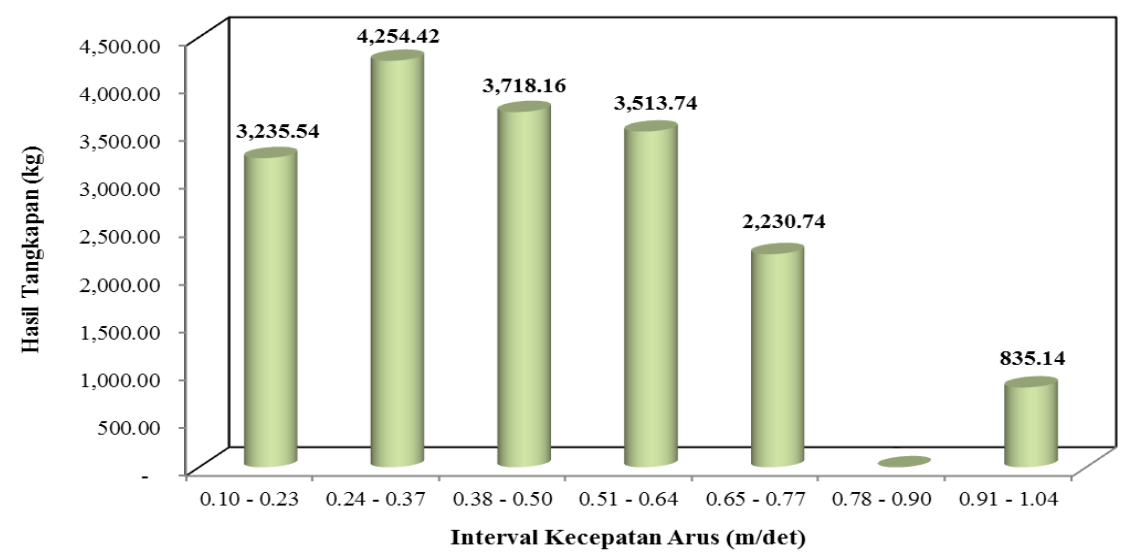

Gambar 14.Grafik Hubungan Kecepatan Arus dengan Hasil Tangkapan Teri

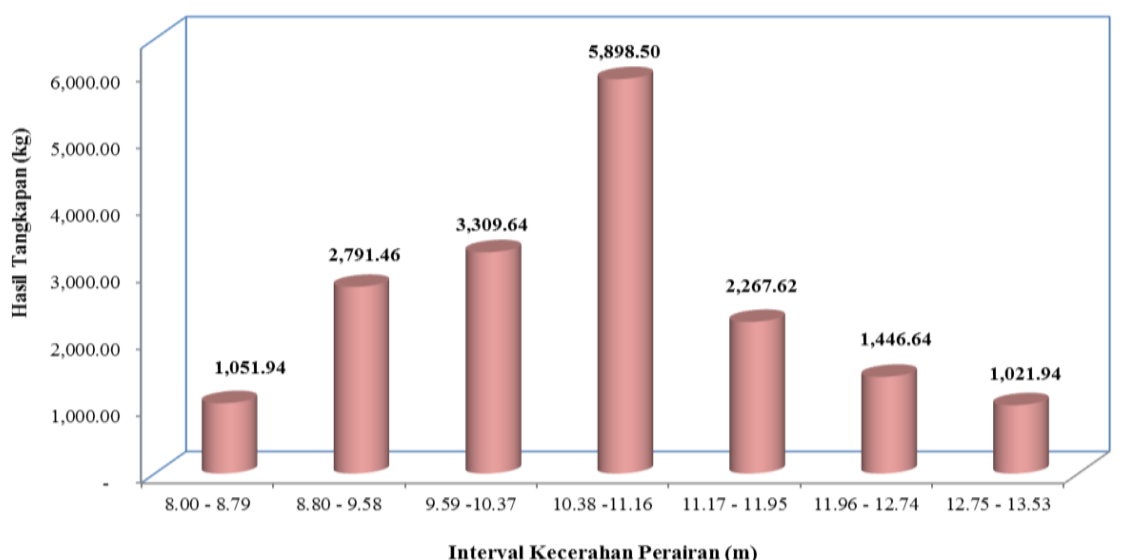

Gambar 15.Grafik Hubungan Kecerahan Perairan dengan Hasil Tangkapan Teri 
Gambar diatas memperlihatkan bahwa hasil tangkapan ikan teri terbanyak diperoleh pada rentang kecerahan perairan 10,38-11,16 meter sebanyak 5.898,50 kg yang diperoleh dari 14 trip penangkapan. Sedangkan hasil tangkapan terrendah diperoleh pada rentang kecerahan 12,75-13,53 meter sebanyak $1.021,94 \mathrm{~kg}$. Secara umum kecerahan yang bagus untuk memperoleh hasil tangkapan teri yang optimum pada rentang 8-11 meter di perairan teluk Dodinga.Kecerahan sangat berpengaruh terhadap jarak penglihatan pada ikan khususnya dalam mencari makan.

Hasil Uji korelasi antara kecerahan perairan dengan Hasil Tangkapan Ikan Teri mendapatkan nilai sebesar 0.0702. Ini menunjukan bahwa ada hubungan antara kecerahan perairan dengan hasil tangkapan namun memiliki kareakter yang sangat lemah (mendekati nol). Hasil penelitian Sudirman et al., (2006) juga menemukan hal yang mirip dimana secara deskriptif kecerahan tidak memperlihatkan hubungan dan pengaruh yang nyata terhadap hasil tangkapan

\section{KESIMPULAN DAN SARAN}

\section{Kesimpulan}

Selama penelitian (November dan Desember) didapati bahwa terjadi dinamika pada kelima faktor oseanografi (suhu permukaan laut, salinitas, kecerahan, kecepatan angin dan kecepatan arus) yang diteliti pada teluk Dodinga. Kabupaten Halmahera Barat diman faktor faktor tersebut masih berada dalam rentangan parameter perairan yang ditolelir oleh ikan teri.

\section{Saran}

Perlu dilakukan kajian parameter oseanografi diatasa lebih lama (misalnya setahun) dan penambahan parameter lain untuk mengetahui dampaknya terhadap perikanan ikan teri di Teluk Dodinga dan aktivitas Bagan Perahu

\section{DAFTAR PUSTAKA}

Alwi, D., Kaparang, F.E. dan Patty. W. 2014. Kajian penggunaan intensitas cahaya lampu yang berbeda terhadap hasil tangkapan bagan perahu di perairan Teluk Dodinga, Kabupaten Halmahera Barat. Aquatic Science \& Management, Vol. 2, No. 2, 38-43 (April 2014) Pascasarjana, Universitas Sam Ratulangi

Azis., M. F. 2006. Gerak Air di Laut. Oseana, Volume XXXI, Nomor 4, Tahun $2006: 9$ - 21. ISSN 02161877.

Baskoro M. S. 1999. Capture Proces Of The Floated Bamboo-Platfrom Lif Net With Ligth Attraction (Bagan) Garaduate School Of Fisheries Tokyo University Of Fisheries.Doctoral Cause Of Marine Sciances And Thecnology P. 149

Dahuri, R., J. Rais, S. P. Ginting, dan Sitepu W. 2013. Pengelolaan Sumber Daya Wilayah Pesisir dan Lautan Secara Terpadu. Balai Pustaka Press: Cetakan ke 5, 328 hal, p.36. Jakarta.

Gaspersz, V. 1991. Metode Perancangan Percobaan untuk ilmu-ilmu Pertanian, Ilmu-Ilmu Biologi. Bandung: Armico. 271 hal.

Haikal, V. M., Taofiqurahman, A dan Riyantin I. 2012. Analisis Massa Air di Perairan Maluku Utara. Jurnal Perikanan dan Kelautan. Volume 3. No. 1. ISSN: 20883137. Fakultas Perikanan dan Kelautan. Universitas Pajajaran. Halaman 1-9

Hutabarat, S dan Stewart M. E. 2008. Pengantar Oseanografi. Universitas indonesia, Jakarta.

Kalangi, P.N.I., Mandagi, A., Masengi, K.W.A., Luasunaung A., Pangalila., F.P.T. dan Iwata M. 2013. Sebaran Suhu dan Salinitas di Teluk Manado. Jurnal Perikanan dan Kelautan Tropis. Vol. IX-2. 
Fakultas Perikanan dan Ilmu Kelautan Universitas Sam Ratulangi, Manado.

Kusuma. C.P.M.. Boesono H. dan Fitri, A. D. P. 2014. Analisis hasil tangkapan ikan teri (Stolephorus sp.) dengan alat tangkap bagan perahu berdasarkan perbedaan kedalaman di perairan morodemak. Journal of Fisheries Resources Utilization Management and Technology. Universitas Diponegoro Volume 3. Nomor 4. Tahun 2014. HIm 102-110

Luasunaung, A. 2011. Analisis Musim Penangkapan Ikan Teri (Stolephorus sp) di Teluk Dodinga Kabupaten Halmahera Barat. Jurnal Perikanan dan Kelautan Tropis. Vol. VII-1, April 2011.

Nasution., A. K, Sari., T. E.Yulika dan Usman. 2015. Fishing Season Review Bilis/Teri (Stelopherus Spp) In The District Of Asam Waters Strait Meranti Islands Province Riau. Jurnal Online Mahasiswa Bidang Perikanan dan Ilmu Kelautan. Volume 2 No. 2. Halaman 1-10.

Nining, S. N. 2002. Oseanografi Fisis. Kumpulan Transparansi Kuliah Oseanografi Fisika, Program Studi Oseanografi, ITB

Nybakken. J.W. 1992.Biologi Laut Suatu PendekatanEkologis. PT Gramedia. Jakarta. 488. Hal.

Norman, Y., Ihsan., $\mathrm{N}$ dan Arsyad M. 2012. Analisis Distribusi Arus Permukaan Laut Di Teluk Bone Pada Tahun 2006-2010.Jurnal Sains dan Pendidikan Fisika. Jilid 8, Nomor 3, Desember 2012, hal $288-295$

Pariwono, J. I. 1998. Kondisi Oseanografi Perairan Pesisir Lampung. Proyek Pesisir Publication, Technical Report. Coastal Resources Centre. University of Rhode Island. Jakarta. Indonesia. 28 Halaman.
Peristiwadi T. 2006. Ikan-ikan Laut Ekonomis Penting di Indonesia, Petunjuk Identifikasi. LIPI Press. Jakarta Indonesia.

Priyatno. D 2009.SPSS (Analisis Korelasi. Regresi dan Multivariat) Cetakan Pertama. Penerbit Gava Media. Yagyakarta.

Rasyid, A. J., 2011. Pemetaan Pola Pergerakan Arus Permukaan Pada Musim Peralihan Timur-Barat Di Perairan Spermonde. Globë Volume 13 No 1 Juni $2011: 8$ 14

Safruddin, Gaffar K., Zainuddin M., dan Mallawa A., 2016. Profil Sebaran Horisontal Suhu Permukaan Laut Dan Klorofil-A Pada Daerah Penangkapan Ikan Teri Di Perairan Kabupaten Luwu Teluk Bone. Jurnal IPTEKS PSP, Universitas Hassanusin. Vol.3 (5) April 2016: 383-391. ISSN: 2355729X.

Safruddin. Zainuddin. M dan Tresnati J. 2014. Dinamika Perubahan Suhu Dan Klorofil-A Terhadap Distribusi Ikan Teri (Stelophorus spp) Di Perairan Pantai Spermonde. Pangkep. Jurnal IPTEKS PSP. Universitas Hassanudin. Vol. 1 (1) April 2014: 11 - 19 ISSN: 2355-729X.

Santosa S. 2014. Statistik Parametrik. Konsep dan Aplikasi dengan SPSS. Elex Media Komputindo. Kelompok Gramedia. Jakarta.

Steel R.G.D dan Torrie JH. 1980. Principles and Procedures of Statistics, McGraw Hill Book Company.

Stewart, R. H., 2008. Introduction To Physical Oceanography. Texas: Department of Oceanography Texas A \& M University.

Sudirman, M.S. Baskoro, A.Purbayanto, Safruddin1 A. Latif dan Surahman. 2006. Hubungan Antara Kecerahan Perairan dan Kecepatan Arus Dengan Hasil Tangkapan dan Pengoperasian Bagan Rambo 
di Selat Makassar. Sorihi, 1 (5) Universitas Khairun Ternate. hal 1-18.

Tanto, T. A., Wisha. U.J., Kusumah. G, Pranowo. W.S dan Husrin S., 2017. Karakteristik Arus Laut Perairan Teluk Benoa-Bali. Jurnal Ilmiah Geomatika Loka Riset Sumber Daya dan Kerentanan Pesisir, BRSDMKP KKP Volume 23. No. 1 Mei 2017: 37-48.

Wahyono, A dan Prabowo S.P., 2009. Sistem Operasi Kapal Purse Seine Asal Jawa dengan Nelayan Pantai Kalimantan Selatan di Selat Makasar. Jurnal Ariomma Vol. 25 No. 22-26 Th. 2009. hal 1-15

Wantasen, A. S. J dan Tamrin. 2012. Analisis Kelayakan Lokasi Budidaya Rumput Laut di Perairan Teluk Dodinga Kabupaten Halmahera Barat. Jurnal Perikanan Kelautan Tropis. Volume VIII-1. Universitas Sam Ratulangi, Manado. 